\title{
Kearifan Lokal dan Benturan Budaya Orang Indonesia di Negara Luar dalam Novel Edensor Karya Andrea Hirata
}

\section{Fauzi Rahman ${ }^{1}$, Ryan Hidayat ${ }^{2}$}

FBS, Universitas Indraprasta PGRI

E-mail : fauzierachman20@yahoo.com

FTMIPA, Universitas Indraprasta PGRI

E-mail : ryansastra3@gmail.com

\begin{tabular}{ll}
\hline Informasi artikel & \\
\hline Sejarah artikel: & \\
Diterima & 09-I2-2017 \\
Revisi & 03-04-2018 \\
Dipublikasikan & Mei 2018 \\
&
\end{tabular}

\section{Kata kunci:}

Kearifan lokal

Nasionalisme

benturan budaya

novel

Edensor

\begin{abstract}
ABSTRAK
Penelitian ini bertujuan untuk mengetahui citra tentang nilai-nilai kearifan lokal dan benturan budaya orang Indonesia yang membawa misi nasionalisme di negara luar, dalam novel Edensor karya Andrea Hirata. Metode yang digunakan dalam penelitian ini adalah deskriptif kualitatif dengan teknik analisis isi. Teknik analisis isi berarti secara tekstual mencari kata-kata, kalimat-kalimat, atau gagasan-gagasan yang terkait dengan topik penelitian untuk kemudian data yang diperoleh tersebut disajikan, diverifikasi, dan ditarik kesimpulannya. Hasil yang diperoleh dari penelitian ini menunjukkan bahwa aspek budaya lokal terlihat lebih menonjol atau lebih dominan dari aspek lainnya, disusul oleh aspek agama, adat, serta sosial. Dominannya aspek budaya lokal yang terdapat oleh para tokoh di dalam novel tersebut karena para tokoh yang digambarkan secara jelas tetap memiliki kesadaran untuk mempertahankan budaya mereka meskipun berada pada gempuran budayabudaya Barat. Jika ini dianalogikan sebagai representasi orang Indonesia, maka kesadaran inilah yang diusung Edensor. Keberhasilan para tokohnya memenangkan pertaruhan mengunjungi sebanyak mungkin negara menumbuhkan rasa percaya diri dan bangga sebagai bangsa Indonesia. Kesadaran bahwa meskipun Indonesia masih morat-marit, masih tertinggal dalam hal ilmu dan teknologi, telah tumbuh kesadaran untuk berani maju dan menempa diri dalam persaingan global. Sangat memungkinkan untuk bangsa ini berubah menjadi lebih baik, bukan hanya dalam penguasaan ilmu, tetapi juga dalam perbaikan sikap dalam mempertahankan kearifan lokalnya, pun seandainya sedang berada di luar negeri.
\end{abstract}

\section{ABSTRACT}

Key word:

Local wisdom

Nationalism

Cultural clashes

Novels

Edensor
This study aims to find out the image of the values of local wisdom and cultural clash of Indonesian people who bring the mission of nationalism in the country outside, in the novel Edensor by Andrea Hirata. The method used in this research is qualitative descriptive with content analysis technique. Content analysis technique means textually searching for words, sentences, or ideas related to the research topic to then the data obtained are presented, verified, and drawn conclusions. The results obtained from this study indicate that the aspects of local culture appear more prominent or more dominant than other aspects, followed by aspects of religion, custom, and social. The dominant aspect of local culture is that of the characters in the novel because the clearly described figures still have an awareness to defend their culture despite the onslaught of Western cultures. If this is analogous to the representation of the people of Indonesia, then this awareness that carried Edensor. The success of the characters won the bets visiting as many countries as possible to foster self-confidence and pride as the nation of Indonesia. The realization that even though Indonesia is still a moratorium, still lagging behind in science and technology, has grown awareness to dare to advance and forge itself in global competition. It is possible for this nation to change for the better, not only in the mastery of science, but also in the improvement of attitudes in maintaining local wisdom, even if it was abroad. 


\section{Pendahuluan}

Novel merupakan sastra imajinatif yang memiliki sifat rekaan semata. Namun begitu, novel bukan berarti penuturan kejadian yang tidak pernah terjadi. Sejalan dengan pendapat Lailasari dan Nurlailah (2006:I66-I67), yang menerangkan bahwa novel merupakan karangan prosa yang panjang, mengandung rangkaian cerita kehidupan seseorang dengan orang-orang di sekelilingnya dengan menonjolakan watak dan sifat setiap pelaku, atau suatu cerita yang fiktif dalam panjang yang tertentu yang melukiskan para tokoh, gerak, dan adegan kehidupan nyata yang respontatif dalam suatu alur atau suatu keadaan yang berisi model kehidupan yang diidealkan, dunia imjinatif yang dibangun melalui berbagai unsur intrinsiknya seperti peristiwa, plot, tokoh, (dan penokohan), latar atau setting, sudut pandang dan lain-lain yang tentu saja bersifat imajinatif.

Novel merupakan cerita yang menampilkan kejadian yang luar biasa pada kehidupan tokohtokohnya. Kejadian-kejadian tersebut menyebabkan perubahan sikap hidup atau menentukan nasib tokoh itu sendiri. Novel merupakan roman yang lebih pendek. Novel mempunyai struktur pembangun cerita yang berupa unsur intrinsik, yang membangun dari dalam karya sastra tersebut (Wiyanto, 2005:7785). Pendapat tersebut, sejalan dengan Esten (2000:12) yang menjelaskan bahwa novel merupakan pengungkapan dari fragmen kehidupan manusia (dalam jangka yang lebih panjang) di mana terjadi konflik-konflik yang akhirnya menyebabkan terjadinya perubahan jalan hidup antara para pelakunya.

Novel terkadang murni merupakan hasil pemikiran dan imajinasi seorang penulis, namun terkadang juga merupakan penuturan kejadian yang memang pernah terjadi, akan tetapi sudah direkayasa atau ditambahkan beberapa imajinasi oleh pengarang agar lebih memiliki unsur dramatisasi dan unsur estetika, sehingga lebih menarik untuk dibaca. Salah satu novel yang merupakan rekaan yang diambil dari cerita yang pernah terjadi adalah dalam tetralogi Laskar Pelangi karya Andrea Hirata. Dalam karya tulis ini, penulis menganalisis novel Edensor yang merupakan salah satu dari tetralogi tersebut.

Penelitian ini akan mendeskripsikan gagasan dalam tiga gagasan. Bagian pertama akan membahas tentang nilai kearifan lokal, dan yang kedua membahas tentang benturan kebudayaan yang keduanya terkandung dalam novel Edensor.

Kearifan lokal terjadi di setiap wilayah di seluruh Nusantara, kearifan lokal adalah warisan leluhur di masa lampau berupa kebudayaan, adat, yang terjadi dalam suatu wilayah hingga sampai saat ini masih mentradisi dan menjadi anutan masyarakat pengikutnya. Sartini (2004) dalam artikelnya berjudul Menggali Kearifan Lokal Nusantara sebuah Kajian Filsafati, menjelaskan bahwa kearifan lokal atau local genius sebagai Local Wisdom. Local Genius ini merupakan istilah yang mula pertama dikenalkan oleh Quaritch Wales. Para antropolog membahas secara panjang lebar pengertian Local Genius ini. Ayatrohaedi (I985:I9-I8) mengutip Soebadio, mengatakan bahwa Local Genius adalah juga Cultural Identity. Identitas atau kepribadian budaya bangsa yang menyebabkan bangsa tersebut mampu menyerap dan mengolah kebudayaan asing sesuai watak dan kemampuan sendiri.

Gobyah (2003) mengatakan bahwa kearifan lokal (localgenius) adalah kebenaran yang telah mentradisi atau ajeg dalam suatu daerah. Kearifan lokal terbentuk sebagai keunggulan budaya masyarakat setempat maupun kondisi geografis dalam arti luas. Kearifan lokal merupakan produk budaya masa lalu yang patut secara terus-menerus dijadikan pegangan hidup. Meskipun bernilai lokal, tetapi nilai yang terkandung di dalamnya dianggap sangat universal.

Dilanjutkan oleh Ayatrohaedi (I985) bahwa unsur budaya daerah potensial sebagai local genius karena telah teruji kemampuannya untuk bertahan sampai sekarang. Ciri-cirinya adalah: (I) mampu bertahan dengan budaya luar; (2) memiliki kemampuan mengakomodasi unsur-unsur budaya luar; (3) mempunyai kemampuan mengintegrasi unsur budaya luar ke dalam budaya asli; (4) mempunyai kemampuan mengendalikan; dan, (5) mampu memberi arah perkembangan budaya.

Selanjutnya, budaya Ki Hajar Dewantara (dalam Supartono, 2004:3I) menjelaskan bahwa budaya merupakan hasil perjuangan manusia terhadap dua pengaruh kuat, yaitu alam dan zaman yang merupakan bukti kejayaan hidup manusia untuk mengatasi berbagai rintangan dan kesukaran di dalam hidup, guna mencapai keselamatan dan kebahagiaan yang pada lahirnya bersifat tertib dan damai.

Segala aspek kearifan lokal di Nusantara, kita adalah kekayaan budaya yang tak ternilai sebagai sumber gagasan yang tak ada habisnya, tinggal bagaimana seniman merespon budaya lokal ini ke dalam struktur karya seninya, Seni yang berbasis kearifan lokal perlu terus dikembangkan dengan mengangkat roh yang ada di dalam sendi-sendi kehidupan yang merupakan kearifan lokal agar seni yang diciptakan dapat mencerminkan kepribadian dan jati diri seniman juga bangsanya yakin seni yang berkarakter Nusantara Indonesia.

Edensor adalah buku ketiga tetralogi Laskar Pelangi karya Andrea Hirata. Seperti yang telah 
banyak diketahui, buku ini merupakan kelanjutan perjalanan hidup Ikal bersama Arai ketika berhasil meraih mimpinya untuk belajar di salah satu universitas tertua dan terkemuka dunia, Université de Paris, Sorbonne, Perancis. Dengan keluguan yang kadang-kadang terkesan kampungan, Ikal dan Arai datang, bertemu, dan berinteraksi dengan berbagai macam manusia dari berbagai belahan dunia dengan perbedaan kebudayaan yang menonjol. Persinggungan Ikal dan Arai dengan berbagai bangsa ini dan petualangan keduanya berkeliling Eropa, bahkan hingga ke Zaire, Afrika disajikan dengan plot dan narasi Andrea Hirata yang seperti biasanya mengalir, mudah dicerna, dan penuh humor tapi dengan bumbu keharuan. Karena itulah, tentunya menjadi menarik mengikuti cara pandang Ikal sebagai tokoh sekaligus narator dalam melihat dan memahami bangsa lain serta dirinya sendiri sebagai bangsa Indonesia. Dengan cara pandang yang kadang-kadang stereotipikal terbungkus humor, Edensor mengukuhkan supremasi bangsa Eropa sekaligus menyentak kesadaran nasional melalui kritiknya tentang mental bangsa Indonesia. Selanjutnya, dibahas juga bagaimana benturan budaya yang digambarkan itu bukan hanya mengukuhkan supremasi bangsa Eropa, tapi juga memberi kritik bagi pembentukan kesadaran nasional.

\section{Metode}

Penelitian ini menggunakan metode deskriptif kualitatif dengan teknik analisis isi. Semi (2012:30) mengemukakan bahwa metode penelitian deskripstif kualitatif adalah data yang terurai dalam bentuk kata-kata atau gambar-gambar, bukan dalam bentuk angka-angka. Sedangkan untuk analisis isi, Moleong (2013:220) menjelaskan mengenai kajian isi yang merupakan teknik apapun yang digunakan untuk menarik kesimpulan melalui usaha menemukan karakteristik pesan, dan dilakukan secara objektif dan sistematis.

\section{Hasil dan pembahasan}

Kearifan lokal merupakan sikap sosial individu yang memegang teguh budaya asli baik di daerah yang bersangkutan, maupun sedang berada di luar daerah dimana individu tersebut merupakan pendatang. Dalam penelitian ini, penulis membagi kearifan lokal ke dalam empat bagian diantaranya adalah budaya, agama, sosial, dan adat. Berikut, penulis merepresentasikan aspek kearifan lokal tersebut yang terdapat di dalam novel Edensor karya Andrea Hirata, yang hasilnya dapat dilihat pada tabel berikut.
Tabel I. Representasi Kearifan Lokal dalam Novel Edensor

\begin{tabular}{|c|c|c|c|}
\hline No & $\begin{array}{l}\text { Nilai } \\
\text { Kearifan } \\
\text { Lokal }\end{array}$ & $\begin{array}{l}\text { Representasi } \\
\text { Kearifan Lokal }\end{array}$ & Hlm. \\
\hline I & Budaya & 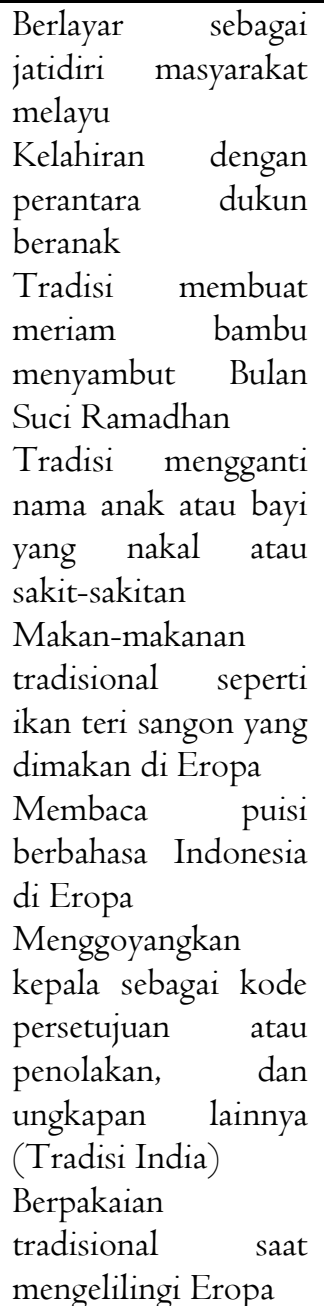 & $\begin{array}{l}94 \\
\text { I2I- } \\
\text { I22 }\end{array}$ \\
\hline 2 & Agama & 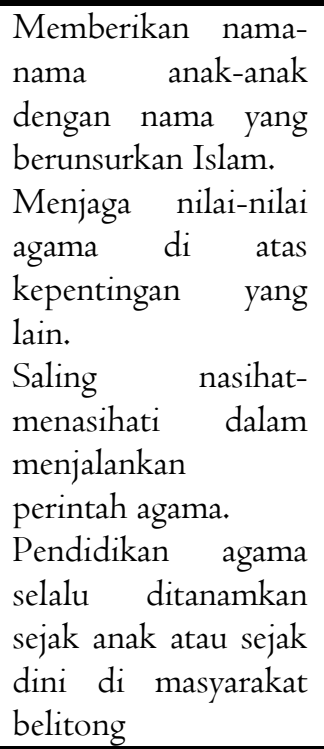 & $\begin{array}{l}\text { I4 } \\
26 \\
\text { I } 57 \\
247\end{array}$ \\
\hline 3 & Sosial & $\begin{array}{l}\text { Menjenguk teman, } \\
\text { kerabat, atau saudara } \\
\text { yang sedang sakit. }\end{array}$ & 4 \\
\hline
\end{tabular}




\begin{tabular}{|c|c|c|}
\hline & $\begin{array}{l}\text { Rela berkorban } \\
\text { untuk orang lain. } \\
\text { Bermusyawarah } \\
\text { untuk bermufakat } \\
\text { (Demokratis) } \\
\text { Tolong-menolong } \\
\text { sesama manusia } \\
\text { walaupun tidak } \\
\text { saling mengenal } \\
\end{array}$ & $\begin{array}{l}21 \\
223\end{array}$ \\
\hline 4 Adat & $\begin{array}{l}\text { Tidak mau } \\
\text { mengecewakan } \\
\text { kepercayaan orang } \\
\text { tua kepada anak } \\
\text { Bersikap tegas } \\
\text { kepada siapapun } \\
\text { yang berlaku tidak } \\
\text { sopan } \\
\text { Penerapan hukuman } \\
\text { sebagai pendidikan } \\
\text { kepada anak-anak di } \\
\text { Belitong yang } \\
\text { berbuat kesalahan } \\
\text { atau melanggar } \\
\text { kesopanan dengan } \\
\text { Tidak boleh laki-laki } \\
\text { berbicara dang } \\
\text { perempuan di } \\
\text { bukan mahrom dialam atau } \\
\text { tengah malam } \\
\text { malam hari }\end{array}$ & $\begin{array}{l}\text { II } \\
\text { I8 } \\
21 \\
23\end{array}$ \\
\hline
\end{tabular}

Kearifan lokal dapat dilihat saat Ikal menceritakan semasa kelahirannya yang dibantu oleh Mak Birah, Dukun beranak yang membantu proses kelahiran Ikal. Pada bagian tersebut, Ikal menyebutkan kata "Nyalo" yang pada masa sebelumnya diucapkan oleh Mak Birah.

Selanjutnya, mengenai masalah kebudayaan tentunya juga erat kaitannya dengan alat budaya. Salah satunya adalah meriam mainan yang terbuat dari bamboo, yang biasa digunakan oleh orang Indonesia atau Melayu khususnya dalam novel ini pada saat menjelang ataupun memperingati bulan suci Ramadhan. Kebiasaan ini merupakan tradisi dan kearifan lokal yang sejatinya merupakan ciri khas orang Melayu yang digambarkan dalam novel tersebut.

Dalam budaya Belitong, menamai anak berarti berharap penuh bahwa sang anak akan berperilaku sebagaimana makna yang terkandung dalam namanya. Apabila nama yang baik tidak diikuti oleh perilaku baik juga dari anak, berarti ada yang salah dalam namanya, dengan begitu penggantian nama harus dilakukan agar sang anak lebih baik lagi dalam berperilaku. Ini adalah sebuah budaya dan kearifan lokal yang sangat taat dipatuhi. Budaya mengganti nama pun digambarkan dalam novel Edensor ini.

Identitas lokal yang digambarkan dalam novel Edensor ternyata tidak serta merta hanya ditunjukkan oleh tokoh dari Indonesia saja. Hal tersebut juga bisa kita lihat dari orang-orang atau teman-teman yang ada di sekitar Ikal dan Arai. Contohnya saja pada tokoh Monahar Vikram Raj Chauduri Manooj atau teman-temannya biasa memanggil dengan sebutan yang lebih singkat, yaitu MVRC Manooj. Tokoh ini merupakan kebangsaan India yang tetap berpegang pada karakteristiknya sebagaimana orang India lokal. Hal tersebut dapat kita lihat dari kutipan berikut.

"Ia berkulit legam, kurus tinggi, dan berwajah jenaka tipikal India. Bulu matanya lentik, lehernya panjang. Gaya berjalannya seperti orang ingin menari. Rupanya, ia memang seorang penari, penari goyang kepala yang piawai. Jika menari kepala, lehernya seperti engsel peluru: naik, turun, maju, mundur, patah-patah, menjulur-julur, dan berputar meliuk-liuk. Ditimpali dendang tabla, ia selalu menjadi hiburan di kelas. Kawan, goyang kepalanya itu bukan perkara sederhana, tapi semacam cultural gesture. Jika MVRC Manooj menggoyang kepalanya terus-menerus, artinya ia sedang menghormati kawan bicaranya. Jika ia bergoyang tiga kali maksudnya: Apa maksudmu? Aku tak mengerti. Empat kali: Baiklah, akan kupertimbangkan. Lima kali mematuk-matuk cepat: Aku mau buang air!" (Hlm.I2I-I22)

"Kuceritakan pada MVRC Manooj bahwa aku walk out dari Katya, ia menggoyangkan kepalanya tujuh kali. Kamu bodoh sekali! Itulah maknanya." (Hlm. I77178)

"Lelaki Punjab itu menggoyangkan kepalanya ke depan, lalu ke kiri kanan, dan ke belakang tiga kali, persis bangau kena jerat cekik. Artinya: Aku Yakin!"

"Meledaklah suasana. Sebagian pengunjung mendukung MVRC Manooj. Ia menggoyang-goyangkan lagi kepalanya, lemah gemulai tak henti-henti, tanda hormat pada pendukungnya. Ruangan disesaki euforia musim panas." (Hlm. I87)

Dari kutipan di atas, dapat kita ketahui bahwa kebudayaan yang melekat dalam diri MVRC Manooj merupakan sebuah konvensi yang sangat unik dan mungkin hanya ada di tanah India. Konvensi yang demikian unik tersebut hanya akan dipahami oleh orang yang memang berasal dari 
tempat dengan situasi sosial yang sama, ataupun bisa juga dipahami oleh orang-orang yang terbiasa bersama seperti halnya Ikal yang sangat memahami maksud dari kode gelengan kepala yang dilakukan oleh MVRC Manooj karena memang teman dekat. Kendatipun dia berada di sebuah Negara maju yang modern, tapi dia tetap dengan karakter khasnya sebagai seorang Hindustan. Hal tersebut merupakan sebuah kearifan lokal yang melekat dan tidak mudah pudar dalam diri seseorang.

Selain itu, dalam kearifan lokal beragama, dalam novel Edensor terlihat saat orang-orang Belitong memberikan nama-nama anak-anaknya dengan nama yang berunsurkan Islam. Hal ini bukanlah hal yang main-main untuk orang Belitong. Menamai anak berarti menentukan anak tersebut akan berperilaku seperti apa. Oleh karena itu, pada novel Edensor orang-orang menamai anaknya sekaligus memberikan doa-doa yang tersirat dalam arti nama sang anak yang kebanyakan menggunakan nama Arab.

Kehidupan beragama sangat diaplikasikan dalam budaya di Belitong yang digambarkan dalam novel ini. Dalam menjalankan kehidupan beragama, masyarakat Melayu sangat serius menyikapinya dan tidak berani bermain-main jika sudah berurusan dengan ketuhanan. Masyarakat di belitong yang digambarkan dalam novel Edensor sangat menomorsatukan hal-hal yang bersifat keagamaan. Kendati berada pada situasi ekonomi yang tidak terlalu baik, tapi jika sudah masuk pada permasalahan agama, mereka sangat serius.

Pendidikan agama ternyata memang sudah selalu ditanamkan sejak anak atau sejak dini di masyarakat belitong. Setinggi apapun pendidikan dan disiplin ilmu yang dipelajari, namun ditekankan untuk tetap tidak lepas dari ajaran agama, dalam hal ini adalah ajaran agama Islam.

Selanjutnya, Berbicara masalah kearifan lokal pada aspek kehidupan sosial tentunya merupakan hal yang sangat erat kaitannya. Hal tersebut memang sangat berkaitan karena di negara kita yang merupakan negara dengan budaya ramah-tamah yang kuat sangat dekat dengan kehidupan sosial.

Salah satu karakteristik yang merupakan ciri bangsa timur, khususnya Melayu yang dilukiskan dalam novel Edensor adalah budaya bermusyawarah untuk mengambil keputusan. Bermusyawarah adalah suatu sikap sosial saat seseorang atau sekelompok orang akan mengambil suatu keputusan yang penting. Dalam novel Edensor ini, musyawarah terlihat pada saat ayah Ikal sedang mencari nama yang cocok untuk mengganti nama anaknya.

Selanjutnya, Adat istiadat merupakan perilaku seseorang ketika berhadapan dengan kondisi budayanya yang menentukan hal-hal yang sesuai dengan kebudayaan itu sendiri. Pada bagian pertama novel, saat Ikal yang sedang bersama Weh, harus pulang karena ada Ujian Sekolah yang akan diikutinya, menunjukkan bahwa Ikal berpegang pada adat bahwa ia harus mengikuti ujian dan meninggalkan Weh. Mengapa mengikuti ujian sekolah merupakan suatu keharusan dan masuk ke dalam adat, hal tersebut karena Ikal tentu tidak mau mengecewakan orang tuanya.

Dalam budaya ketimuran khususnya Indonesia yang lekat dengan ajaran Islamnya, menaati perintah orang tua merupakan suatu kewajiban mutlak dan tidak bisa ditawar-tawar lagi. Dengan tidak mengikuti Ujian Sekolah, berarti tidak akan lulus, dengan tidak lulus berarti akan sangat mengecewakan orangtua. Hal tersebutlah yang menjadi pertimbangan Ikal untuk meninggalkan Weh selama dua minggu.

Dalam budaya ketimuran, penerapan adat istiadat sangatlah keras di kalangan masyarakat Belitong khususnya dalam kehidupan yang digambarkan di novel Edensor. Sebagai contohnya pada saat tokoh Ikal membuat ulah dengan cara menyalakan mercon bambu pada saat orang-orang shalat tarawih. Dengan tegas orang-orang di sekitar dan orang tua Ikal mengambil sikap tegas agar tokoh Ikal berperilaku lebih baik lagi.

\section{Benturan Budaya Orang Indonesia di Negara Luar}

Pada dasarnya, Edensor menggambarkan orang Indonesia dalam dua bentuk pencitraan: positif dan negatif. Positifnya, melalui perilaku Ikal dan Arai sebagai perwakilan bangsa Indonesia, orang Indonesia digambarkan kreatif, berkemauan keras, dan patriotik. Namun, di sisi lain, orang Indonesia digambarkan memiliki kompleks rendah diri dan sedikit tinggi hari. Dibungkus humor, gambaran orang Indonesia di Eropa tersebut menimbulkan berbagai kelucuan yang malah ironis.

Sebagai dua orang Indonesia, khususnya berasal dari perkampungan yang sedikit tertinggal kemajuannya, Ikal dan Arai tentu saja mengalami gegar budaya di benua yang maju dan modern itu. Bisa dibayangkan bagaimana orang yang tidak pernah mengalami musim dingin tiba-tiba harus terjebak semalam dalam dinginnya suhu di luar rumah! Untunglah berkat pengetahuan Arai tentang tentara Prusia yang mampu bertahan hidup di kejamnya cuaca dingin Rusia, keduanya menjalani malam itu dengan selamat. Bagaimana mereka bertindak gila dengan berani mengambil resiko keliling Eropa tanpa bekal yang memadai. Meskipun Ikal memiliki motivasi tambahan terselubung, yaitu mencari A Ling. Atau bagaimana Ikal dan Arai bertahan dengan 
memakan dedaunan dan mengandalkan lifting untuk membawa mereka keluar dari Rusia yang kejam.

Tokoh Ikal memegang teguh budaya ketimurannya meskipun dikelilingi oleh kawankawannya yang berasal dari budaya Barat. Meskipun teman-temannya mabuk-mabukan, mengaitkan anting di hidung, memakai narkoba, mendengarkan musik keras, dan melakukan seks bebas, akan tetapi, Ikal tetap tidak mengikuti apa yang dilakukan oleh kawan-kawannya dan lebih memilih untuk mempertahankan apa yang menjadi budayanya. Dari sini mulai terlihat betapa kebudayaan yang terbiasa diimplikasikan Ikal di Indonesia seakan terbentur dengan yang dia hadapi di Eropa. Hal tersebut dapat terlihat dari pernyataannya pada kutipan novel berikut ini.

"Sering aku merasa heran. Kawan-kawanku The Britzs, yankee, kelompok Jerman, dan Belanda adalah para pub crawler kawakan. Mereka senang bermabuk-mabukan. Tak jarang mereka mabuk mulai Jumat sore dan baru sadar Senin pagi. Sebagian hidup seperti bohemian, mengaitkan anting di hidung, mencandu drugs, musik trash metal, berorientasasi seks ganjil, dan tak pernah terlihat tekun belajar, namun mereka sangat unggul di kelas. Aku yang hidup seuai dengan tutntutan Dasa Dharma Pramuka taat pada perintah pada orang tua, selalu belajar dengan giat dan tak lupa minum susu, jarang dapat melebihi niai mereka." (Hlm. III-II2)

Selanjutnya, nasionalisme serta patriotisme Ikal dan Aray muncul saat melihat CD Anggun dan mendengar suaranya serta mengetahui orang-orang Perancis mengenalnya dan mengagumi suara penyanyi Indonesia Tersebut.

"Anggun membuatku bangga menjadi orang Indonesia," (hlm.87)

Demikian kata Ikal. Patriotisme ini muncul kembali saat mereka terlibat dalam pertaruhan menaklukkan Eropa. Mau tidak mau gengsi bangsa dipertaruhkan, dan alangkah bangganya Ikal dan Arai saat mereka memenangkan pertaruhan itu sehingga

"...rasanya ingin kunyanyikan lagu

"Indonesia Raya”." (hlm.273)

Kurangnya rasa bangga menjadi bangsa Indonesia diakui sendiri oleh Ikal. Perasaan bangga jarang sekali muncul selama ia berada di tanah air. Ketidakbanggaan ini juga menjadi sebab rendah diri orang Indonesia di kancah hubungan internasional. Lihat saja bagaimana orang Indonesia yang berada di kantor Uni Eropa. Sementara bangsa lain datang dan tampak antusias dan bergairah, “...di pojok sana, aku melihat segelintir manusia yang rasanya kukenal. Aku sering melihat mereka bertengkar soal minyak tanah di televise tanah air. Mereka kelihatan semakin tidak penting dengan sosoknya yang kecil diantara raksasa hitam dan putih. Agak berbeda dengan delegasi lain, mereka kurang percaya diri, sedikit malu-malu, tertunduk-tunduk memasuki kantor Uni Eropa. Ini pasti soal utang piutang." (hlm. 68).

Atau, bagaimana kikuknya Ikal harus bersikap saat Katya yang cantik itu mengungkapkan rasa cintaya pada Ikal. Ikal yang belum pernah memiliki seorang pacar dan hanya menginginkan A Ling dalam mimpinya, tiba-tiba mendapatkan seorang dewi langsung ke dalam pelukannya. Kata Ikal,

"Aku sadar diri, dari seluruh kemungkinan logis ketertarikan pria wanita secara fisik, materialistic, filosofik, idealism, kultur, ekspektasi, kemistri, gengsi, atau apapun, tak secuil pun aku memenuhi kualifikasi Katya."(hlm.II3).

Perasaan rendah diri pula yang merasuki Ikal dan Arai saat ditolak tinggal di apartemen oleh Vand Der Wall. Meskipun Van Der Wall tidak memperlakukan mereka selayaknya manusia, yang ada dalam asumsi Ikal adalah penghinaan yang akan mereka terima karena mereka berasal dari negara yang memang buruk birokrasinya:

"Kulihat Arai ingin marah ... Tapi kami tahu sikap itu hanya akan membuat Van Der Wall memuntahkan kata-kata yang lebih menyakitkan, misalnya: Itu bukan urusanku! Silakan menggelandang di luar, itu urusan kalian! Nasib kalian sial karena ketololan kalian sendiri! Atau, begitulah cara kalian orang Indonesia bekerja! Tak ada sistem! Tak bisa antisipasi! Tak efisien sama sekali!" (hlm. 60)

Namun yang paling parah, perasaaan rendah diri terutama sekali tergambar dalam Mozaik I7: the Pathetic Four. Rupanya di universitas berkelas internasional ini, kesamaan budaya menyatukan kelompok secara alamiah. Dengan proporsi yang lebih banyak, orang Inggris dan Amerika mendominasi kelas. Sementara orang Jerman, Belanda, Yahudi dan China bergabung dengan kelompoknya masing-masing. Ikal, yang menjadi satu-satunya orang Indonesia secara "terpaksa" bergabung dengan kelompok marjinal bersama Manooj yang orang India, Gonzales si orang Meksiko, dan Ninochka, gadis Georgia. The Pathetic Four ini bergabung lantaran kesamaan latar 
belakang yang sama, yaitu karena ketidakfasihan penguasaan bahasa asing ilmiah. Sebagai orang-orang yang berasal dari negara dunia ketiga, seakan memperkuat inferioritas bangsa dunia ketiga, keempat sekawan ini pun hanya bercita-cita lulus seadanya sehingga dapat menghabiskan waktunya untuk menonton bola.

Herannya, meskipun dilanda rasa rendah diri yang agak akut, orang-orang Indonesia, baik melalui perilaku Ikal maupun yang lainnya, bersikap tinggi hati. Seperti yang dikatakan Ikal sendiri,

"Aku teringat akan bangsaku, bangsa yang gemar membanggakan diri padahal babak belur karena carut marut" (hlm. 88).

Misalnya, ketika mereka kembali memiliki uang setelah kelaparan di Rusia, Ikal dan Arai berbelanja untuk menyenangkan hati, biarpun norak. Dengan narasi lucu yang menggelitik Ikal mengenakan kacamata ray ban, baju dan celana baru yang memberi efek mirip pimpinan orkes dangdut. Sementara Arai membelanjakan uangnya untuk sebuah jam yang menurutnya sebuah jam Swiss Army asli. Betapa menggelikannya ketika kaca jam itu dengan mudah pecah saat terkena goncangan keras.

Ikal, sebagai bagian dari bangsa yang merupakan minoritas dari segi kultur dan kemampuan secara akademis dibandingkan dengan teman-teman Barat lainnya, menempatkan dirinya dengan rendah hati sebagai bagian the Pathetic Four, kelompok yang termarjinalkan karena kekurangfasihan mereka akan pakem akademis Barat. Selain itu sikap rendah diri Ikal dalam persaingan memperebutkan Katya menyiratkan peran statis tipikal Timur yang selalu digambarkan Barat:

“...dari seluruh kemungkinan logis

ketertarikan pria wanita secara fisik, materialistik, filosofik, idealism, kultur, ekspektasi, kemistri, gengsi, atau apapun, tak secuil pun aku memenuhi kualifikasi Katya."(hal.II3)

Meskipun sedikit tertarik, darah ketimuran yang mengalir tetap mencegah Ikal turut serta dalam persaingan cinta tersebut. Ikal merasa tak pantas bersaing. Pencitraan Barat dan Timur yang ditemukan dalam Edensor seolah menegaskan pandangan superioritas antara bangsa Barat dengan Timur.

Menarik untuk dianalisis bahwa meskipun hegemoni Barat sangat terasa dalam novel ini, ada sebuah resistensi dan kritik terhadap superioritas Barat ini. Ikal sebagai tokoh utama yang merupakan wakil kultur Timur menyadari seperti apa kecil posisinya ketika berada di antara orang-orang barat,
Terutama pada awal kedatangannya di Eropa. Ikal menyanjung kekuatan Barat melalui penggambaran kota dan institusi Uni Eropa dan pencitraan orang Eropa yang ditemuinya minus Van Der Wall. Argumentasi Ikal sebagai orang pertama menempatkan dirinya sebagai pelaku yang terpesona dan memandang Barat sebagai tujuannya. Praduga Ikal tentang penolakan tinggal di apartemen dikaitkannya dengan kemungkinan pandangan Barat tentang Indonesia. Demikian pula saat Ikal beberapa kali merujuk mengapa bangsa Eropa, khusunya Belanda, dapat menguasai bangsa lainnya. Seolaholah itu adalah hal yang alamiah atau karena kesalahan bangsa terjajah (Indonesia) sendiri. Representasi adopsi ini bisa diambil secara simbolis dari hubungan Ikal dan Katya. Tawaran kencan Katya seolah menjadi legitimasi penerimaan Ikal di dunia Eropa, karena sebelumnya Ikal bukan hanya merasa tak pantas bersaing, bahkan memang tidak layak.

Selanjutnya, terdapat tahap dimana tidak hanya terjadi penerimaan tetapi juga penyelarasan terhadap model Barat tadi. Bagian dimana Ikal dan Arai memulai petualangannya adalah tahap ini. Ide mengamen yang ditawarkan Famke disambut keduanya dengan antusias. Ide gila yang semula diragukan kawan-kawan Eropanya, malah memicu keduanya untuk menjalankan ide itu. Boleh saja Ikal dan Arai berkostum putri duyung sebagai bagian pendanaan petualangannya di Eropa, tetapi mereka mengadaptasi pose dengan kreativitasnya sendiri. Artinya, pembelajaran cara Barat dengan modal ala Timur.

Pada bagian ini juga Ikal menggambarkan sisi lain Eropa yang tidak gemerlap. Ikal melihat Eropa dengan berbagai kontradiksinya. Kemudian ia juga memberikan penilaian berdasarkan budaya Timurnya, termasuk kegeramannya akan penjajahan saat mengunjungi Gronigen. Pemicu kesadaran akan budayanya antara lain kedatangan surat dari Ayahandanya. Ketika ia bermimpi menjadi ahli ekonomi, ayahnya memintanya menjadi ahli pupuk karena itulah yang menurut sang ayah diperlukan negerinya:

"Dadaku sesak karena keluguan surat itu telah membuatku merasa sangat malu pada diriku sendiri, pada harapan duniawiku yang egois dan materialistik. Ayahku dengan ketulusannya yang tak terukur, dengan pensium Rp 87.300,- masih bersemangat memikirkan nasib orang-orang di kampungnya, masih sempat memikirkan apa yang terbaik untuk bangsanya." (hal.I42) 
Kenangan dan nasihat sang ayah seolah mengingatkan Ikal yang telah larut dalam kehidupan Eropanya. Pelan-pelan plot bergulir menuju pencarian diri.

Terakhir, terdapat kemandirian tanpa referensi pada norma Eropa. Perjalanan Ikal membawanya kembali ke budaya asalnya: Timur dan Islam. Pertemuannya dengan imam masjid di Austria, dengan seorang brother Moslem dan akhirnya seorang suster di Zaire membawanya pada akhir pencarian -bukan kepada A Ling, melainkan kepada dirinya sendiri. Dalam kaitannya dengan pencitraan bangsa, tidak terasa lagi perasaan rendah diri seperti juga tak tersirat lagi perasaan snobbish. Keberhasilan memenangkan pertaruhan berkelana dan keberhasilan pribadi menyelesaikan tesisnya agaknya meningkatkan rasa percaya diri Ikal. Hal yang ditegaskan dalam pelajaran moral nomor dua belas bagi Ikal:

"Ke mana pun tempat telah kutempuh, apa pun yang telah kucapai, dan dengan siapa pun aku berhubungan, aku tetaplah seorang lelaki udik, tak dapat kubasuh-basuh.” (Hlm.I60)

Dalam novel ini, pada intinya Ikal mengalami proses beradaptasi sekaligus merasa asing, tetapi akrab dalam budaya barunya. Bertitik tolak dari itu, Ikal berubah, menjadi manusia Indonesia yang lebih kritis. Ia membandingkan budayanya sendiri dengan budaya Barat untuk kemudian memetik pelajaran tentang mengapa bangsa ini tertinggal dalam hal ilmu dan sikap.

\section{Simpulan}

Representasi kearifan lokal pada aspek budaya lokal terlihat lebih menonjol atau lebih dominan dari aspek lainnya, disusul oleh aspek agama, adat, serta sosial. Dominannya aspek budaya lokal yang terdapat oleh para tokoh di dalam novel tersebut merupakan sebuah kearifan karena para tokoh yang digambarkan secara jelas tetap mempertahankan budaya mereka meskipun berada pada gempuran budaya-budaya Barat. Tidak lupanya para tokoh baik itu Ikal, Aray, maupun tokoh pendukung lain terhadap budaya asli mereka sebagai ciri khas mereka sebagai masyarakat pendatang merupakan sebuah karakter, dan kearifan lokal seorang individu di dalam sebuah kebudayaan baru yang sangat bertolak belakang dengan budaya yang mereka pahami.

Dalam perjalan meraih cita-citanya, Ikal, khususnya, mendapati bahwa menjadi orang Indonesia di Eropa tidaklah mudah. Melalui tokoh Ikal, tampak bahwa orang Indonesia mendapat kesulitan bersaing dengan orang Eropa Eropa Barat, secara akademis. Orang Eropa digambarkan menguasai kelas dan peradaban. Sementara orang Indonesia, melalui Ikal, harus berjuang mati-matian untuk bertahan baik secara fisik maupun mental.

Melalui pergaulannya dengan bangsa-bangsa Eropa, Ikal membandingkan budaya Indonesia dan budaya Barat. Seringkali budaya Barat diagungkan Ikal dan budaya Indonesia dikritik. Ketidakbanggaan Ikal sebagai orang Indonesia di awal cerita adalah karena ketidakmampuan birokrat Indonesia mengurus warga negaranya. Hal inilah yang membuat Ikal dan Aray terlunta-lunta saat tiba di Eropa. Ditambah pula dengan perilaku ironis birokrat Indonesia yang berhutang dari negara-negara maju, tapi tidak mencerminkan kesederhanaan.

Dalam analisis yang dilakukan, terlihat juga adanya kesadaran dalam diri Ikal bahwa ia mampu dan layak duduk sejajar dengan bangsa lain. Jika ini dianalogikan sebagai representasi orang Indonesia maka kesadaran inilah yang diusung Edensor. Keberhasilannya memenangkan pertaruhan mengunjungi sebanyak mungkin negara menumbuhkan rasa percaya diri dan bangga sebagai bangsa Indonesia. Kesadaran bahwa meskipun negeri ini masih morat-marit, masih tertinggal dalam hal ilmu dan teknologi, telah tumbuh kesadaran untuk berani maju dan menempa diri dalam persaingan global tergambarkan dalam novel ini. Adalah sebuah keniscayaan untuk berubah menjadi lebih baik bukan hanya dalam penguasaan ilmu tetapi juga dalam perbaikan sikap.

\section{Persantunan}

Artikel ini disusun atas dorongan dan dukungan dari berbagai pihak. Ucapan terimakasih disampaikan kepada Universitas Indraprasta PGRI dan teman-teman sejawat. Ucapan terima kasih juga disampaikan kepada tim editorial Bahastra Pendidikan Bahasa dan Sastra Indonesia Universitas Ahmad Dahlan yang telah memberikan ruang untuk penerbitan artikel ini. Semoga artikel ini dapat memberikan kontribusi dalam pembelajaran terutama dalam kegiatan literasi kritis.

\section{Daftar Pustaka}

Ayatrohaedi. 1985. Kepribadian Budaya Lokal (Local Genius). Jakarta: Pustaka Jaya.

Esten, Mursal. 2000. Kesusastraan, Pengantar Teori dan Sejarah. Bandung: Angkasa.

Gobyah, I Ketut. 2004. Berpijak pada Kearifan Lokal dalam http://www.balipos. 2003.

Hirata, A. 2007. Edensor. Yogyakarta: Bentang. 
Moleong, Lexy J.. 2013. Metodologi Penelitian Kualitatif. Bandung: Rosda.

S. Lailasari dan Nurlailah S.S. 2006. Kamus Istilah Sastra. Bandung: Nuansa Aulia.

Sartini, 2004, Menggali Kearifan Lokal Nusantara sebuah Kajian Filsafati, Jurnal filsafat, Jilid 37. Nomor 2.

Semi, M. Atar. 2012. Metode Penelitian Sastra, Bandung : CV Angkasa.

Supartono. 2004. Ilmu Budaya Dasar. Bogor: Ghalia Indonesia.

Wiyanto, Asul. 2005. Kesusastraan Sekolah Penunjang Pembelajaran Bahasa Indonesia SMP dan SMA. Jakarta: PT Grasindo. 